\title{
PENGARUH KEPIPIHAN DAN KELONJONGAN AGREGAT TERHADAP PERKERASAN LENTUR JALAN RAYA
}

\author{
M. Aminsyah ${ }^{1}$
}

\begin{abstract}
ABSTRAK
Penyediaan material konstruksi jalan yang sesuai dengan persyaratan dan spesifikasi yang berlaku merupakan salah satu cara untuk meningkatkan kualitas jaringan jalan. Material utama pembentuk lapisan perkerasan jalan adalah campuran agregat (90-95\% dari berat campuran perkerasan) dan aspal. Agregat kasar berupa batu pecah pada umumnya didapat dari hasil pemecahan batu-batu berukuran besar oleh alat pemecah batuan (stone crusher). Bentuk butir yang paling banyak ditemukan yaitu berbentuk kubus (persegi), pipih (flaky) dan lonjong (elongated).

Pada penelitian ini diteliti pengaruh bentuk butiran pipih (flakyness) dan bentuk butiran lonjong (elongated) terhadap perkerasan lentur jalan raya. Penelitian ini menggunakan campuran Hot Rolled Sheet Wearing Course (HRS-WC). Penelitian ini memperbandingkan campuran standar yang sesuai dengan spesifikasi (agregat kasar dan agregat halus menggunakan batu pecah) dengan beberapa kombinasi pemakaian agregat kasar pipih/lonjong untuk campuran perkerasan.
\end{abstract}

Hasil penelitian didapatkan persentase penggunaan agregat kasar yang pipih/ lonjong yang aman digunakan sebagai material adalah sebesar $43 \%$ dimana apabila melebihi nilai tersebut, maka parameter Marshall yang didapatkan tidak sesuai dengan spesifikasi campuran HRS-WC lagi.

Kata Kunci : parameter Marshall, Hot Rolled Sheet Wwearing Course (HRS-WC), flakyness, elongated.

\section{PENDAHULUAN}

\subsection{Latar Belakang}

Kekuatan dan keawetan suatu konstruksi perkerasan jalan sangat tergantung dari kualitas agregat, daya dukung tanah tersebut serta jenis aspal yang digunakan sebagai bahan utama untuk mengikat material-material tersebut hingga didapatkan suatu perkerasan yang awet, tahan lama, kuat dan kesat. Dua jenis perkerasan yang biasa digunakan yaitu perkerasan lentur yang menggunakan aspal sebagai bahan pengikatnya dan perkerasan kaku yang menggunakan semen sebagai bahan pengikat agregat. Adapun agregat sebagai komponen utama dari perkerasan jalan raya ini terdiri dari agregat kasar dan agregat halus yang mempunyai proporsi masing-masing sesuai dengan spesifikasi yang digunakan. Agregat kasar merupakan agregat yang terdiri dari batu pecah atau kerikil pecah yang bersih, kering, kuat, awet, dan bebas dari bahan lain yang akan mengganggu, serta agregat halus merupakan pasir alam atau pasir buatan yang bebas dari gumpalan-gumpalan lempung dan merupakan butiran yang bersudut tajam dan mempunyai permukaan yang kasar.

Agregat kasar berupa batu pecah umumnya didapat dari hasil pemecahan batu-batu berukuran besar oleh alat pemecah batu (stone crusher). Hasil pemecahan alat stone crusher didapatkan berbagai ukuran dan bentuknya. Bentuk butir yang paling banyak didapatkan dari penggunaan alat ini adalah kubus (persegi), pipih (flaky) dan lonjong (elongated). Agregat berbentuk kubus adalah agregat

\footnotetext{
${ }^{1}$ Staf Pengajar Jurusan Teknik Sipil Fakultas Teknik Universitas Andalas
} 
yang terbaik digunakan sebagai material perkerasan jalan hal ini dikarenakan agregat tersebut mempunyai bidang kontak yang lebih luas sehingga dapat saling mengunci dengan baik. Sementara itu agregat pipih dan agregat lonjong pada umumnya juga dihasilkan oleh stone crusher, sehingga dilapangan tidak dapat dihindari pemakaian kedua bentuk agregat tersebut.

Disebabkan hal yang demikian maka dilakukan penelitian pengaruh bentuk butiran pipih (indeks kepipihan) dan bentuk butiran lonjong (indeks kelonjongan) terhadap perkerasan lentur jalan raya. Metode penentuan indeks kepipihan didasarkan kepada klasifikasi partikel agregat sebagai benda pipih (flaky) dengan ketebalan kurang dari 0,6 ukuran nominalnya. Sedangkan metode penentuan indeks kelonjongan didasarkan pada klasifikasi partikel agregat sebagai benda lonjong (elongated).

Parameter utama untuk menilai kelayakan bentuk butiran pipih dan lonjong sebagai agregat pada perkerasan lentur didapatkan dari pengujian Marshall. Hasil dari penelitian ini akan dipaparkan dalam bentuk tabel dan grafik uji Marshall, sehingga diharapkan didapat gambaran kelayakan penggunaan agregat berbentuk pipih dan lonjong.

\subsection{Tujuan Penelitian}

Penelitian ini bertujuan untuk melihat kelayakan penggunaan agregat pipih dan lonjong sebagai bahan perkerasan lentur jalan raya.

\subsection{Batasan Masalah}

Yang menjadi batasan masalah pada penelitian ini, adalah sebagai berikut :

1. Material yang digunakan adalah batu pecah sebagai agregat kasar dan agregat halus.

2. Agregat kasar yang pipih dan lonjong adalah berupa batu pecah.

3. Bahan pengikat yang digunakan adalah aspal.

4. Semen Portland digunakan sebagai bahan pengisi (filler).

5. Spesifikasi yang digunakan adalah perkerasan lentur dengan jenis Hot Rolled Sheet (HRS) yang digunakan oleh Kimpraswil (Bina Marga)

\section{TINJAUAN PUSTAKA}

\subsection{Agregat}

\subsubsection{Kualitas Agregat}

Agregat adalah bahan keras yang apabila dipadatkan sehingga bersatu kuat akan membentuk struktur pokok bangunan jalan dengan atau tanpa penambahan bahan pengikat. Kualitas dan sifat agregat sangat menentukan dalam memikul beban lalu lintas, yang apabila kualitas dan sifatnya yang baik diperlukan untuk lapisan permukaan (surface) yang akan langsung memikul beban lalu lintas dan mendistribusikannya ke lapisan bawah (base coarse). Oleh karena itu agregat yang akan digunakan harus mempunyai kualitas tinggi, yang tergantung kepada :
a. Kekerasan Agregat.
b. Permukaan Butir Agregat.
c. Kelekatan Agregat terhadap Aspal.
d. Ketahanan Agregat terhadap Cuaca.

\subsubsection{Syarat Mutu Agregat}

\subsubsection{Ukuran dan Gradasi}

Semua lapisan perkerasan lentur membutuhkan agregat yang terdistribusi dari ukuran besar sampai kecil. Distribusi partikel-partikel berdasarkan ukuran agregat atau gradasi merupakan hal yang

\section{J JRNAL REKAYASA SIPIL}




\section{Aminsyah}

penting dalam menentukan stabilitas perkerasan. Gradasi dapat dibedakan atas, gradasi seragam (uniform graded), gradasi rapat (dense graded) dan gradasi buruk (poorly graded).

\subsubsection{Bentuk Butir}

Bentuk dan tekstur agregat mempengaruhi stabilitas dari lapisan perkerasan yang dibentuk oleh agregat tersebut.

\subsubsection{Daya Absorbsi}

Agregat yang berpori banyak akan menyerap aspal lebih banyak, sehingga aspal akan masuk kedalam pori yang mengakibatkan campuran akan kekurangan aspal.

\subsubsection{Daya Lekat Terhadap Aspal}

Tergantung dari keadaan pori dan banyaknya pori-pori dalam agregat.

\subsubsection{Pengolahan Agregat}

Material terdiri dari penggalian pasir dan kerikil serta penggalian batuan.

\subsubsection{Penggilingan}

Objek Penggilingan dalam memproduksi agregat adalah penurunan ukuran kedalam batas yang lebih spesifik, dengan jumlah produksi minimum untuk material yang baik.

\subsubsection{Mesin Pemecah Batuan}

Mesin Pemecah Batuan dengan cara berputar menjepit dan berbentuk seperti kerucut adalah sangat penting dalam memproduksi agregat, sebagian besar untuk mencapai penurunan ukuran dengan menekan sesama partikel sehingga relatif cenderung dapat meratakan.

\subsubsection{Mesin Pemecah Jepit}

Kebanyakan dari mesin ini terdiri dari satu set bidang penggiling dan cenderung dapat bergerak dengan beberapa alternatif yaitu bergerak relatif lambat menuju atau menjauh dari bidang penggiling.

\subsubsection{Mesin Pemecah Berputar (Gyratory Crusher)}

Tampilan yang esensial dari alat ini meliputi satu set kerucut yang bergerak menanjak naik secara keseluruhan didalam kerucut terbalik dengan berbagai sudut.

\subsubsection{Peremuk Kerucut (Cone Crusher)}

Cone Crusher mirip dengan gyratory crusher kecuali pada mesin perata yaitu dalam bentuk kerucut dengan titik yang bergerak naik, dimana hasil dari dua mesin perata menjadi lebih dekat.

\subsubsection{Mesin Pemecah Tumbukan}

Mesin dengan perputaran palu sangat dibutuhkan dalam memproduksi agregat.

\subsection{Analisa Indeks Kepipihan dan Indeks Kelonjongan}

\subsubsection{Indeks Kepipihan (Flakiness Index)}

Suatu partikel agregat dapat dikatakan pipih apabila agregat tersebut memiliki dimensi (ukuran) lebih kecil dari dua dimensi lainnya. Agregat pipih yaitu agregat yang memiliki dimensi lebih kecil dari 0.6 kali rata-rata dari lubang saringan yang mana membatasi ukuran fraksi dari partikel tersebut.

\subsubsection{Indeks Kelonjongan (Elongated Index)}

Suatu partikel agregat dapat dikatakan lonjong apabila agregat tersebut memiliki dimensi (ukuran) lebih besar dari dua dimensi lainnya. Agregat lonjong yaitu agregat yang memiliki dimensi lebih besar dari 1.8 kali rata-rata ukuran lubang saringan yang membatasi ukuran fraksi partikel tersebut. 


\subsection{ASPAL}

Aspal didefenisikan sebagai material berwarna hitam atau cokelat tua, pada temperatur ruang berbentuk padat/agak padat. Hidrokarbon adalah bahan dasar utama dari aspal yang disebut bitumen. Aspal yang umum digunakan saat ini adalah yang berasal dari salah satu hasil proses minyak bumi, dan ada yang langsung berasal dari alam.

\subsubsection{Jenis Aspal}

Berdasarkan dari cara diperolehnya aspal dapat dibedakan atas, Aspal alam (terbagi dari Aspal gunung (Rock Asphalt) dengan contoh aspal dari Pulau Buton dan Aspal Danau (Lake Asphalt) dengan contoh yang terdapat di Trinidad) serta Aspal Buatan yang terdiri dari, Aspal keras/panas (Asphalt Cement), Aspal Cair (Cutback Asphalt), Aspal Emulsi (Emultion Asphalt) dan Ter.

\subsubsection{Fungsi Aspal sebagai Material Perkerasan Jalan}

Aspal yang digunakan sebagai material perkerasan jalan, berfungsi antara lain sebagai :

1. Bahan Pengikat, yaitu memberikan ikatan yang kuat antara aspal dan agregat dan antara sesama aspal.

2. Bahan Pengisi, yaitu untuk mengisi rongga antar butir agregat dan pori-pori yang ada di dalam butir agregat itu sendiri.

\subsubsection{Job Mix Formula}

Merupakan suatu pekerjaan pencampuran antara agregat dengan aspal dalam kadar/proporsi yang telah ditentukan. Empat syarat yang harus dipenuhi untuk mendapatkan lapisan aspal yang baik :

- Stabilitas

Stabilitas perkerasan merupakan kemampuan lapisan menerima beban lalu lintas tanpa mengalami perubahan bentuk.

- Durabilitas (keawetan)

Durabilitas adalah kemampuan dari suatu lapisan untuk menahan pengaruh udara, air, perubahan suhu dan keausan akibat gesekan dari roda kendaraan.

- Fleksibilitas (kelenturan)

Fleksibilitas adalah kemampuan lapis perkerasan untuk mengikuti deformasi yang terjadi akibat beban berulang dari lalu lintas tanpa timbulnya retak dan perubahan volume.

- Ketahanan Geser (skid resistance)

Ketahanan geser adalah kemampuan lapis perkerasan untuk memberikan kekesatan.

Sehingga kendaraan tidak mengalami slip, baik pada waktu kering maupun diwaktu hujan.

\subsection{Jenis Perkerasan}

Berdasarkan bahan pengikatnya, konstruksi perkerasan jalan terdiri atas :

1. Konstruksi perkerasan lentur (flexible pavement).

Perkerasan lentur merupakan jenis perkerasan yang menggunakan aspal sebagai bahan pengikat.

2. Konstruksi perkerasan kaku (rigid pavement).

Perkerasan kaku menggunakan semen sebagai bahan pengikat, yang berupa pelat beton dengan atau tanpa tulangan diletakkan di atas tanah dasar dengan atau tanpa lapis pondasi bawah.

3. Konstruksi perkerasan komposit (composite pavement).

Perkerasan komposit yaitu perkerasan kaku yang dikombinasikan dengan perkerasan lentur dapat berupa perkerasan lentur di atas perkerasan kaku, atau perkerasan kaku di atas perkerasan lentur. 


\subsection{Konstruksi Perkerasan Lentur Jalan Raya}

Perkerasan lentur jalan raya terdiri atas agregat sebagai material utama dan aspal sebagai bahan pengikat dengan atau tanpa bahan tambahan. Material-material pembentuk beton aspal dicampur pada suatu suhu tertentu. Suhu pencampuran ditentukan berdasarkan jenis aspal yang digunakan. Konstruksi perkerasan lentur terdiri dari lapisan-lapisan yang diletakan diatas tanah dasar yang berfungsi menerima beban lalu lintas dan menyebarkannya ke lapisan dibawahnya.

\subsection{Lapis Tipis Aspal Beton}

Lapis Tipis Aspal Beton adalah lapisan penutup konstruksi perkerasan jalan yang tipis, terdiri dari campuran merata dari agregat bergradasi senjang dengan aspal keras yang dicampur, dihamparkan, dan dipadatkan dalam keadaan panas pada suhu tertentu. Karakteristik beton aspal yang terpenting pada campuran ini adalah durabilitas dan fleksibilitas.

\subsection{Hot Rolled Sheet-Wearing Course (HRS-WC)}

Hot Rolled Sheet-wearing Course (HRS-WC) merupakan lapisan aus pada konstruksi jalan yang terdiri dari campuran aspal keras dan agregat yang mempunyai gradasi senjang, dicampur, dihampar dan dipadatkan pada suhu tertentu. Gradasi butiran untuk campuran AC-BC dapat dilihat pada Tabel 1.

Tabel 1. Gradasi Hot Rolled Sheet-Wearing Course (HRS-WC)

\begin{tabular}{|c|c|c|}
\hline \multicolumn{2}{|c|}{ Ukuran Saringan } & \multirow{2}{*}{$(\%)$ Berat yang Lolos } \\
\hline No & Bukaan $(\mathbf{m m})$ & 100 \\
\hline $3 / 4 "$ & 19 & $90-100$ \\
\hline $1 / 2 "$ & 12.5 & $75-85$ \\
\hline $3 / 8 "$ & 9.5 & $59-76$ \\
\hline no. & 4.75 & $50-72$ \\
\hline no. 8 & 2.36 & $40-64$ \\
\hline no. 16 & 1.18 & $35-60$ \\
\hline no.30 & 0.600 & $10-20$ \\
\hline no. 100 & 0.150 & $6-12$ \\
\hline no.200 & 0.075 & \\
\hline
\end{tabular}

\section{METODOLOGI PENELITIAN}

\subsection{Pendahuluan}

Metode penelitian ini diawali dengan melakukan studi literatur yang bertujuan untuk memahami persyaratan dan sifat penggunaan aspal dan agregat pada campuran perkerasan jalan raya. Setelah melaksanakan studi literatur maka dilakukan studi eksperimental yang dilaksanakan di laboratorium. Penelitian ini dilakukan untuk menguji kelayakan penggunaan agregat pipih/lonjong dalam suatu pencampuran untuk perkerasan lentur jalan raya. Penentuan proporsi penggunaan agregat pipih/lonjong tersebut dilakukan berdasarkan persentase fraksi agregat kasar yang dibagi atas persentase agregat kasar (split) menurut spesifikasi dengan persentase agregat kasar yang pipih/lonjong yang kemudian dibuat dalam beberapa kombinasi yang dibuat berdasarkan spesifikasi Hot Rolled Sheet Wearing Course (HRS-WC).

Program kerja secara umum disajikan pada bagan alir yang terdapat pada Gambar 3.1. 


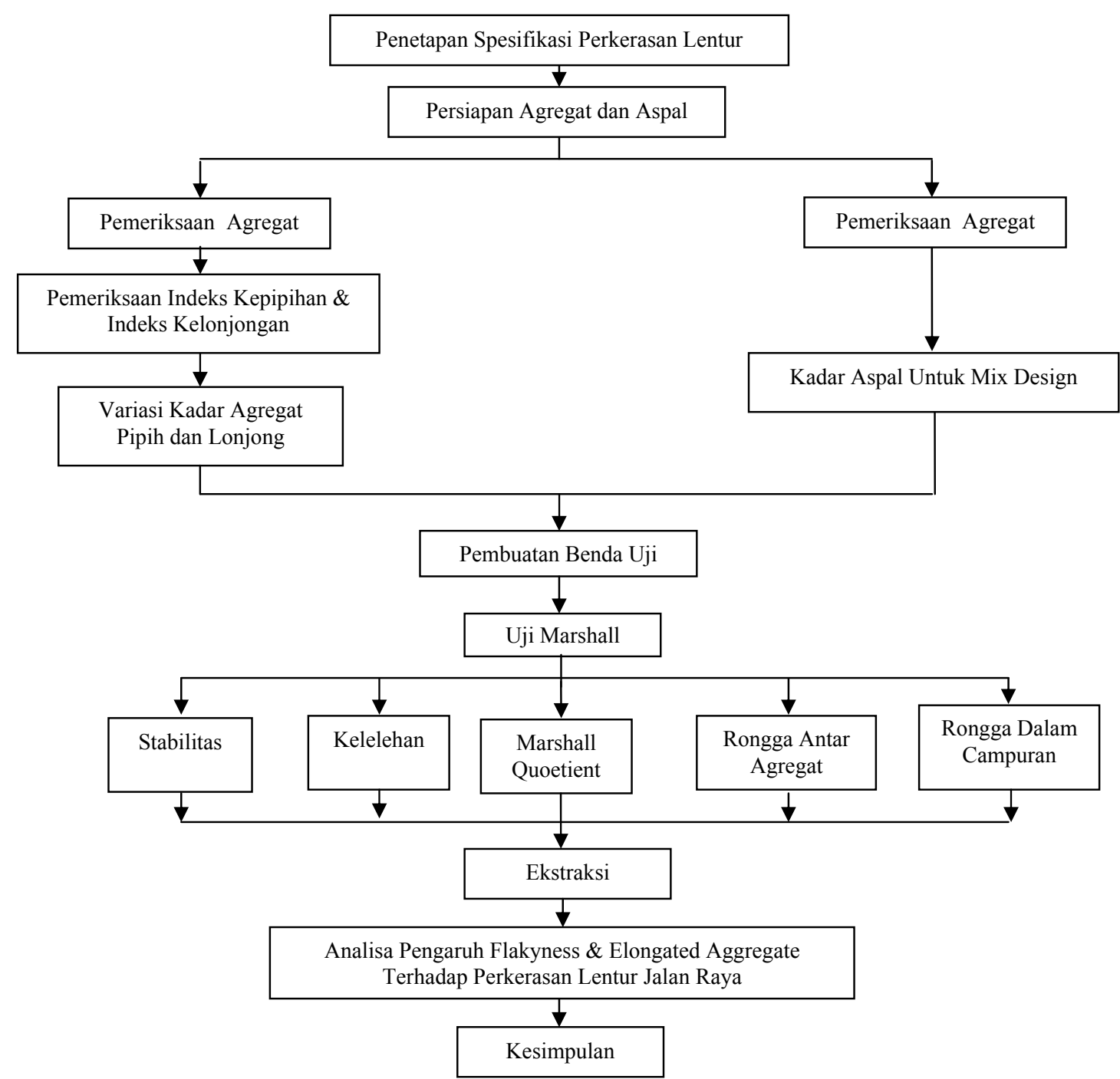

Gambar 1. Diagram Metodologi Penelitian

\subsection{Pemeriksaan di Laboratorium}

Pemeriksaan ini bertujuan untuk memeriksa agregat dan aspal apakah memenuhi persyaratan sesuai dengan spesifikasi pekerjaan jalan atau tidak, selain itu juga berguna untuk menentukan besarnya kebutuhan aspal dan kebutuhan agregat dari suatu perencanaan perkerasan.

\subsubsection{Pemeriksaan Agregat}

1. Analisa Saringan (sieve analysis)

Pemeriksaan ini dimaksudkan untuk menentukan gradasi atau pembagian butiran dari agregat dengan menggunakan saringan.

2. Pemeriksaan berat jenis dan penyerapan agregat

Pemeriksaan ini bertujuan untuk menentukan berat jenis bulk (bulk specific gravity), berat jenis kering kering permukaan (saturated surface dry), berat jenis semu (apparent specific gravity), penyerapan.

3. Pemeriksaan berat isi agregat (volumetric weight aggregate).

Bertujuan untuk mengetahui perbandingan agregat terhadap isi. 


\section{Aminsyah}

4. Indeks kepipihan agregat (flakiness index).

Untuk mengetahui persentase berat agregat pipih yang masih dapat digunakan sebagai bahan perkerasan.

5. Indeks kelonjongan agregat (elongated index).

Untuk mengetahui persentase berat agregat lonjong yang masih dapat digunakan sebagai bahan perkerasan.

6. Pemeriksaan kelekatan agregat terhadap aspal

Bertujuan untuk menentukan persentase luas permukaan agregat yang tertutup aspal terhadap seluruh luas permukaan agregat.

\subsubsection{Pemeriksaan Aspal}

1. Pemeriksaan penetrasi

Dimaksudkan untuk menentukan penetrasi aspal keras atau lunak dengan menggunakan jarum penetrasi, beban dan waktu tertentu pada suhu tertentu.

2. Pemeriksaan berat jenis aspal

Bertujuan untuk mengetahui perbandingan antara berat aspal dengan berat air suling dengan isi yang sama pada suhu tertentu.

3. Pemeriksaan kehilangan berat aspal

Bertujuan menetukan berapa kehilangan berat aspal mula-mula dengan aspal setelah di oven selama 5 jam pada suhu $163{ }^{\circ} \mathrm{C}$.

4. Pemeriksaan titik nyala dan titik bakar

Bertujuan untuk mengetahui berapa suhu pada saat titik nyala dan titik bakar.

5. Pemeriksaan kelekatan aspal terhadap agregat

Bertujuan untuk mengetahui kelekatan aspal pada batuan tertentu.

6. Pemeriksaan daktilitas

Dimaksudkan untuk mengetahui jarak terpanjang yang dapat ditarik antara dua cetakan yang berisi aspal sebelum putus.

\subsection{Menentukan Fraksi Agregat}

Persentase fraksi agregat yang akan digunakan dalam proses pencampuran ini sesuai dengan spesifikasi yang digunakan yaitu Hot Rolled Sheet - Wearing Course (HRS-WC).

\subsection{Menentukan Kombinasi Penggunaan Agregat Pipih/Lonjong}

Pada penelitian ini pemakaian agregat pipih/lonjong dalam pencampuran dibuat dalam tiga kombinasi serta satu campuran standar yang berfungsi sebagai pembanding. Untuk proporsi masing-masing kombinasi dapat diuraikan sebagai berikut :

1. Campuran Standar/ Pembanding, fraksi agregat kasar \& halus sesuai spesifikasi HRS-WC.

2. Variasi I, terdapat fraksi agregat pipih/lonjong $25 \%$.

3. Variasi II, terdapat fraksi agregat pipih/lonjong 37,5\%.

4. Variasi III, terdapat fraksi agregat pipih/lonjong 50\%.

\subsection{Menentukan Kadar Aspal}

Dalam penelitian ini kadar aspal pendahuluan ditentukan dengan menggunakan metode Luas Permukaan.

\subsection{Pengujian Kelayakan Campuran dengan Marshall Test}

Berdasarkan ketentuan Marshall, perencanaan suatu campuran aspal harus memenuhi beberapa syarat dibawah ini : 
1. Cukup jumlah aspal untuk menjamin keawetan.

2. Cukup stabil sehingga dapat menerima beban lalu lintas tanpa mengalami perubahan bentuk.

3. Cukup rongga dalam campuran untuk memungkinkan pemadatan tambahan dan akibat pembebanan lalu lintas.

4. Cukup lentur sehingga memungkinkan perubahan bentuk tanpa terjadi keretakan.

Untuk memperoleh sifat campuran dengan kondisi diatas, dibutuhkan suatu kadar aspal yang optimum untuk merencanakan campuran aspal. Salah satu cara untuk menentukan kadar aspal optimum adalah metode Marshall. Pada rangkaian pengujian dengan alat Marshall, terdapat dua tahap yaitu :

1. Penentuan volume rongga dalam campuran. Setelah dilakukan pencampuran dan pemadatan, benda uji direndam dalam air selama 24 jam pada suhu ruang untuk mendapatkan kondisi jenuh. Kemudian dilakukan penimbangan dalam kondisi setelah pemadatan, dalam air dan dalam kondisi jenuh. Dari perhitungan diatas didapat volume rongga dalam campuran dan rongga antar mineral agregat.

2. Penentuan Stabilitas dan Kelelehan. Penentuan stabilitas dan kelelehan dilakukan dengan alat Marshall pada suhu $60^{\circ}$ dengan kecepatan 2"/menit.

\subsubsection{Stabilitas}

Stabilitas lapisan perkerasan jalan adalah kemampuan lapisan perkerasan menerima beban lalu lintas tanpa terjadi perubahan bentuk yang tetap, seperti gelombang, alur ataupun bleeding. Untuk jenis lapis perkerasan HRS-WC diisyaratkan stabilitas besar dari $800 \mathrm{~kg}$.

\subsubsection{Kelelehan}

Kelelehan adalah perubahan bentuk yang terjadi pada campuran akibat adanya pembebanan. Untuk jenis lapis perkerasan HRS-WC),nilai kelelehan diisyaratkan diatas $2 \mathrm{~mm}$.

\subsubsection{Rongga dalam Campuran (VIM)}

Rongga dalam campuran adalah ruang udara yang terjadi di antara partikel agregat yang telah terselubungi aspal dalam campuran yang telah dipadatkan. Rongga ini dinyatakan dalam persen terhadap volume campuran total. Untuk jenis lapis perkerasan HRS-WC, rongga dalam campuran yang diharapkan berkisar antara $4 \%$ sampai $6 \%$.

\subsubsection{Rongga Antar Aqreqat (VMA)}

Rongga antar mineral agregat adalah rongga udara yang ada diantara partikel agregat dalam campuran yang sudah dipadatkan, termasuk ruang yang terisi. Dengan kata lain rongga antar mineral agregat merupakan ruang yang tersedia untuk menampung volume efektif aspal dan rongga udara yang diperlukan dalam campuran yang dinyatakan dalam $\%$ terhadap volume total benda uji. Untuk campuran HRS-WC disyaratkan rongga antar agregat sedikitnya $18 \%$ dari volume campuran total.

\subsubsection{Marshall Quotient (MQ)}

Angka MQ adalah hasil bagi stabilitas dan kelelehan. MQ merupakan indikator kelenturan yang potensial terhadap keretakan, yang dinyatakan dalam $\mathrm{kg} / \mathrm{mm}$. Untuk jenis lapis perkerasan HRSWC MQ yang diisyaratkan untuk campuran ini adalah diatas $200 \mathrm{~kg} / \mathrm{mm}$.

\subsection{Analisis Karakteristik Campuran}

Sesuai dengan ketentuan Marshall, nilai parameter hanya diwakili oleh satu nilai kadar aspal yang menunjukkan kadar aspal optimum, yang didapat dari analisis masing-masing hubungan parameter dengan kadar aspal. 


\section{Aminsyah}

\section{ANALISIS DAN PEMBAHASAN}

\subsection{Pemeriksaan Agregat}

Pemeriksaan Agregat dilaboratorium meliputi pemeriksaan analisa saringan, pemeriksaan berat jenis dan penyerapan agregat, keausan agregat dengan mesin Los Angeles, pemeriksaan kelekatan agregat terhadap aspal, serta pemeriksaan indeks kepipihan dan kelonjongan agregat. Adapun hasil pemeriksaan agregat tersebut dapat dilihat pada Tabel 2.

Tabel 2. Pemeriksaan Agregat

\begin{tabular}{|c|l|c|c|}
\hline No. & Uraian Pemeriksaan Agregat & Hasil Pemeriksaan Agregat & Spesifikasi \\
\hline 1. & $\begin{array}{l}\text { Pemeriksaan Berat Jenis dan } \\
\text { Penyerapan Agregat }\end{array}$ & $\begin{array}{l}\text { Agregat Kasar : } \\
\text { Berat Jenis }=2,595 \\
\text { Penyerapan }=1,23 \% \\
\text { Agregat Halus : } \\
\text { Berat Jenis }=2,52 \\
\text { Penyerapan }=2,5 \%\end{array}$ & $\begin{array}{l}2,50-2,65 \\
0,5-1,5 \%\end{array}$ \\
\hline 2. & $\begin{array}{l}\text { Pemeriksaan Keausan dengan } \\
\text { menggunakan mesin Los Angeles }\end{array}$ & $\begin{array}{l}2,50-2,65 \\
\text { Maks 3\% }\end{array}$ \\
\hline 3. & $\begin{array}{l}\text { Pemeriksaan Kelekatan Agregat } \\
\text { terhadap Aspal }\end{array}$ & Maks $40 \%$ \\
\hline 4. & $\begin{array}{l}\text { Pemeriksaan Indeks Kepipihan } \\
\text { Agregat }\end{array}$ & $15,30 \%$ & Maks 25\% \\
\hline 5. & $\begin{array}{l}\text { Pemeriksaan Indeks Kelonjongan } \\
\text { Agregat }\end{array}$ & $20,72 \%$ & Maks 25\% \\
\hline
\end{tabular}

\subsection{Pemeriksaan Aspal}

Pemeriksaan aspal di laboratorium meliputi pemeriksaan berat jenis aspal, pemeriksaan penetrasi aspal, titik nyala dan titik bakar aspal dengan menggunakan Cleveland Open Cup, kehilangan berat aspal, dan kelekatan aspal terhadap batuan. Adapun hasil pemeriksaan aspal tersebut dapat dilihat pada Tabel 3.

Tabel 3. Pemeriksaan Aspal

\begin{tabular}{|c|c|c|c|}
\hline No. & Uraian Pemeriksaan Aspal & Hasil Pemeriksaan Aspal & Spesifikasi \\
\hline 1. & Pemeriksaan Berat Jenis Aspal & 1,04 & $1,02-1,04$ \\
\hline 2. & Pemeriksaan Penetrasi Aspal & $\begin{array}{l}\text { Penetrasi dengan kehilangan } \\
\text { berat : } \\
89,3 \\
\text { Penetrasi tanpa kehilangan } \\
\text { berat: } \\
110,8\end{array}$ & Aspal Pen 100/120 \\
\hline 3. & $\begin{array}{l}\text { Pemeriksaan Titik nyala dan Titik } \\
\text { bakar dengan menggunakan } \\
\text { Cleveland Open Cup }\end{array}$ & $\begin{array}{l}\text { Titik Nyala }=280^{\circ} \mathrm{C} \\
\text { Titik Bakar }=300^{\circ} \mathrm{C}\end{array}$ & - \\
\hline 4. & $\begin{array}{l}\text { Pemeriksaan Kehilangan Berat } \\
\text { Aspal }\end{array}$ & $0,035 \%$ & - \\
\hline 5. & $\begin{array}{l}\text { Pemeriksaan Kelekatan Aspal } \\
\text { terhadap Agregat }\end{array}$ & $95 \%$ & $>95 \%$ \\
\hline
\end{tabular}




\subsection{Evaluasi Campuran Pembanding dengan Campuran Kombinasi}

\subsubsection{Penentuan Berat Agregat dan Aspal dalam Campuran}

Berat agregat ditentukan dari persentase tiap fraksi agregat kasar dan halus berdasarkan spesifikasi gradasi agregat campuran untuk Hot Rolled Sheet Wearing Course serta berat jenis agregat campuran.

\subsubsection{Hasil Pemeriksaan Aspal}

Dari hasil pemeriksaan yang didapatkan aspal yang digunakan baik untuk pencampuran dan pada penelitian ini digunakan aspal dengan Penetrasi 100/120.

\subsubsection{Hasil Pemeriksaan Campuran}

Pemeriksaan dilaboratorium meliputi berat awal, berat dalam air, berat ssd, stabilitas dan kelelehan.

\subsubsection{Kadar Aspal Optimum}

Kadar Aspal optimum didapatkan dari hasil pemeriksaan campuran, yang mana pada penelitian ini didapatkan nilai kadar aspal optimum pada kombinasi $1: 6,6 \%$, kombinasi $2: 6,65 \%$, kombinasi 3 : $6,95 \%$.

\subsubsection{Analisis Hubungan Parameter Marshall dan Penqqunaan Agregat Pipih/Loniong pada Campuran Kombinasi}

Analisa ini dilakukan terhadap hasil dari parameter Marshall pada campuran standar, yaitu campuran berdasarkan spesifikasi gradasi agregat campuran dengan hasil dari parameter Marshall pada campuran kombinasi, yaitu campuran dengan menggunakan agregat pipih/lonjong. Adapun campuran kombinasi yang diperbandingkan, yaitu:

1). Variasi I : Campuran Agregat Kasar (terdapat 25\% agregat pipih/lonjong) + Agregat Halus + Filler (PC) + Aspal.

2). Variasi II : Campuran Agregat Kasar (terdapat 37,5\% agregat pipih/lonjong) + Agregat Halus + Filler (PC) + Aspal.

3). Variasi III : Campuran Agregat Kasar (terdapat 50\% agregat pipih/lonjong) + Agregat Halus + Filler $(\mathrm{PC})+$ Aspal.

\subsubsection{Stabilitas}

Hasil stabilitas yang didapatkan dari kombinasi pemakaian agregat pipih/lonjong dalam pencampuran dengan campuran pembanding (sesuai spesifikasi) dapat diketahui bahwa :

Stabilitas (Variasi I > Campuran Pembanding $>$ Variasi II $>$ Variasi III)

Nilai stabilitas yang didapatkan dari semua hasil pemakaian kombinasi agregat pipih/ lonjong ini memenuhi spesifikasi campuran HRS-WC dimana stabilitas $>800 \mathrm{~kg}$.

\subsubsection{Kelelehan}

Dari penelitian yang telah dilakukan didapatkan nilai kelelehan dari campuran, yaitu :

Kelelehan (Variasi III > Variasi II $>$ Variasi I $>$ Campuran Pembanding)

Nilai kelelehan yang didapatkan dari semua hasil pemakaian kombinasi agregat pipih/lonjong ini memenuhi spesifikasi campuran HRS-WC dimana kelelehan merupakan indikator terhadap lentur (fleksibilitas), yaitu kemampuan beton aspal untuk menyesuaikan diri akibat penurunan tanpa terjadinya retak

\subsubsection{Voids in Mix (Rongga dalam Campuran)}

Hasil pengujian didapatkan perbandingan nilai VIM antara campuran pembanding dengan campuran kombinasi dapat diilustrasikan sebagai berikut :

VIM (Campuran Pembanding $>$ Variasi I $>$ Variasi II $>$ Variasi III)

VIM yang didapatkan pada setiap kombinasi memenuhi spesifikasi campuran sebesar 4-6\%.

\section{2 | J URNAL REKAYASA SIPIL}




\section{Aminsyah}

\subsubsection{Voids in the Mineral Aggregate (Rongga antar Butir Agregat)}

Campuran aspal beton HRS-WC mensyaratkan nilai minimum untuk rongga antar butir agregat sebesar $18 \%$. Dari data yang didapatkan untuk pemakaian agregat pipih/ lonjong dibandingkan dengan campuran standar dapat dilihat bahwa :

VMA (Variasi III > Variasi I > Variasi II $>$ Campuran Pembanding)

Pada kombinasi III dengan penggunaan agregat pipih/ lonjong 50\% dalam campuran, didapatkan nilai VMA yang besar dibandingkan yang lainnya. Hal ini disebabkan oleh agregat kasar yang pipih/ lonjong patah menjadi partikel yang lebih kecil sehingga memperbanyak pori antar agregat.

\subsubsection{Marshall Quetient (MQ)}

Untuk campuran HRS-WC ditetapkan nilai Marshall Quetient (MQ) minimal $200 \mathrm{~kg} / \mathrm{mm}$. Hasil pengujian terhadap nilai MQ dapat diilustrasikan sebagai berikut :

MQ (Variasi I > Campuran Pembanding > Variasi II > Variasi III)

Selanjutnya nilai MQ ini dapat digunakan untuk menentukan batas persentase agregat pipih/ lonjong yang masih aman digunakan dalam pencampuran.

\subsection{Evaluasi Penggunaan Agregat Pipih/ Lonjong}

Setelah dilakukan Marshall Test pada benda uji, maka benda uji tersebut diuraikan kembali untuk dilihat persentase kehilangan berat agregat yang hancur pada tiap-tiap kombinasi akibat dari penggunaan agregat pipih/lonjong dalam pencampuran. Dari data yang didapatkan dapat dilihat bahwa persentase kehilangan berat agregat terbesar didapatkan dari Variasi 3 (pemakaian agregat pipih/lonjong sebesar $50 \%$ dalam pencampuran) sebesar 1,706\%. Sementara untuk Variasi 2 didapatkan nilai sebesar $0,381 \%$ dan untuk Variasi 1 sebesar $0,369 \%$.

\section{KESIMPULAN}

Berdasarkan serangkaian pengujian yang telah dilakukan, dapat disimpulkan bahwa :

1. Dari grafik semua kombinasi (campuran pembanding, Variasi 1, Variasi II, dan Variasi III) terhadap Parameter Marshall dapat dilihat bahwa nilai yang didapatkan untuk stabilitas, kelelehan, VIM, VMA, dan Marshall Quetient (MQ) memenuhi spesifikasi campuran Hot Rolled Sheet Wearing Course (HRS-WC). Dari grafik ini juga dapat dilihat bahwa campuran Variasi I (pada agregat kasarterdapat 25\% agregat pipih/lonjong) diusulkan dapat digunakan dengan alasan parameter Marshallnya mendekati campuran standar HRS-WC (campuran pembanding).

2. Dari hasil penelitian didapatkan grafik perbandingan parameter Marshall terhadap $\%$ agregat kasar yang pipih/lonjong yang masih aman digunakan sebagai material untuk pencampuran perkerasan, yaitu persentase agregat kasar yang pipih/ lonjong yang aman digunakan adalah sebesar $43 \%$. Ini berarti penggunaan agregat pipih/lonjong apabila melebihi kadar $43 \%$ tidak baik lagi digunakan dalam pencampuran, hal ini dapat dilihat dari grafik perbandingan MQ terhadap \% pipih/lonjong dimana penggunaan agregat pipih/lonjong yang besar dari $43 \%$ tidak memenuhi spesifikasi campuran HRS-WC lagi $(<$ dari $200 \mathrm{~kg} / \mathrm{mm})$.

\section{DAFTAR PUSTAKA}

Dept,P.U., (1997), Petunjuk Pelaksanaan Lapis Aspal Beton untuk Jalan Raya, Badan Penerbit P.U, Jakarta.

2. Geological Society, (1992), Aggegates : Sand, Gravel and Crushed Rock Aggregates For Construction Purpose.

3. Kreb, D., (1978), Highway Material, Mc.Grawth Hill, Singapore. 

Terhadap Perkerasan Lentur Jalan Raya
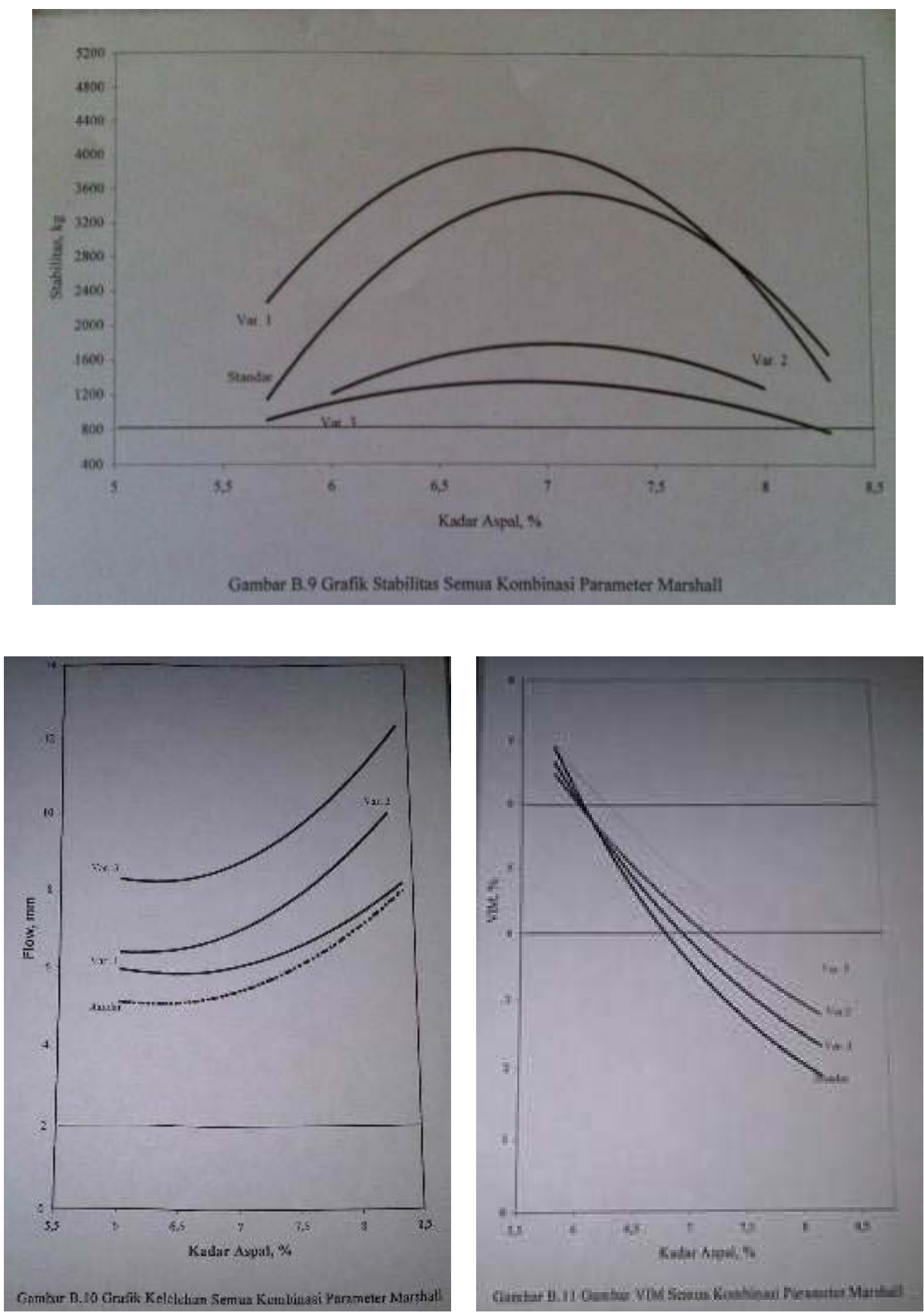

34 | J URNAL REKAYASA SIPIL 
M. Aminsyah
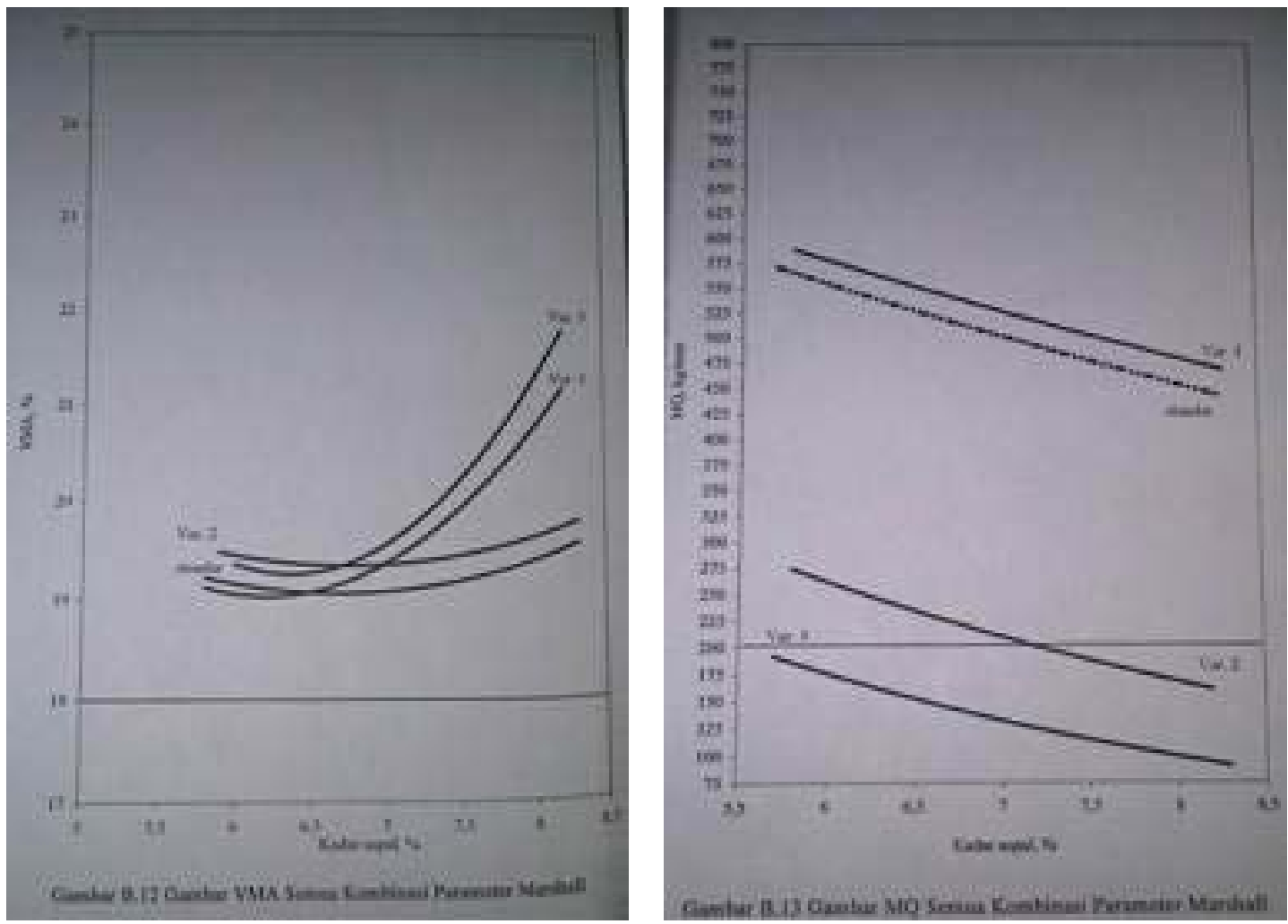
Pengaruh Kepipihan dan Kelonjongan Agregat Terhadap Perkerasan Lentur Jalan Raya

\section{6 | JURNAL REKAYASA SIPIL}

